\title{
ПРЕСТУПНОЕ ОГРАНИЧЕНИЕ КОНКУРЕНЦИИ (ЧАСТЬ 1 СТАТЬИ 178 УК РФ): ПРИЗНАКИ ОБЪЕКТИВНОЙ СТОРОНЫ
}

\author{
И.В. Шишко, О.Е. Деревягина \\ Сибирский федеральный университет, г. Красноярск, Российская Федерация
}

\author{
Информация о статье \\ Дата поступления \\ 26 мая 2016 г. \\ Дата принятия в печать \\ 25 июня 2017 г. \\ Дата онлайн-размещения \\ 29 сентября 2017 г.

\section{Ключевые слова} \\ Ограничение конкуренции; \\ заключение ограничивающего \\ конкуренцию соглашения; \\ признаки картеля; \\ хозяйствующий субъект - \\ конкурент; запрещенность \\ соглашения в соответствии \\ с антимонопольным \\ законодательством РФ

\section{Финансирование} \\ Государственное задание \\ № 2014/52 на выполнение \\ государственных работ \\ в сфере научной деятельности \\ в рамках базовой части проекта \\ № 2706 «Уголовно-правовые \\ и криминологические аспекты \\ противодействия преступности»
}

\begin{abstract}
Аннотация. Статья посвящена исследованию всех признаков объективной стороны ограничения конкуренции. Толкование именно этих признаков вызывает трудности, обусловленные изменением диспозиции ч. 1 ст. 178 УК РФ, ее бланкетным характером и сложностью антимонопольного законодательства, к которому необходимо обращаться и которое, в свою очередь, обновлено «четвертым антимонопольным пакетом». В целях исключения признания преступным ограничением конкуренции противоправных соглашений, не относящихся к картельным, либо слаженного взаимодействия хозяйствующих субъектов, внешне напоминающего картель, авторы исследуют все признаки самого́ картельного соглашения - соглашения, его сторон и последствий, к которым соглашение приводит или может привести. Именно эти последствия (для отграничения от последствий преступления, описанного в ч. 1 ст. 178 УК, авторы именуют их последствиями - признаками самого́ картеля) и описание сторон картеля позволяют распознать его среди других противоправных соглашений. Резюмируется, что корректировка ч. 1 ст. 178 УК и примечаний к данной статье привела к существенной декриминализации ограничения конкуренции, а новеллы в антимонопольном законодательстве - к его частичной криминализации. Учитывая признание законодателем картелей соглашениями, неизбежно влекущими ограничение конкуренции и, следовательно, безусловно запрещенными (per se), авторы анализируют обоснованность включения в объективную сторону преступления признаков запрещенности соглашения в соответствии с антимонопольным законодательством РФ и ограничения конкуренции. Эти признаки авторы в итоге признают необходимыми: они минимизируют риск признания картелем других противоправных соглашений либо признания преступным картеля, допустимого в порядке исключения.
\end{abstract}

\section{CRIMINAL RESTRICTION OF COMPETITION (PART 1 OF ART. 178 OF THE CRIMINAL CODE OF THE RUSSIAN FEDERATION): OBJECTIVE ASPECTS}

Irina V. Shishko, Olga E. Derevyagina

Siberian Federal University, Krasnoyarsk, the Russian Federation

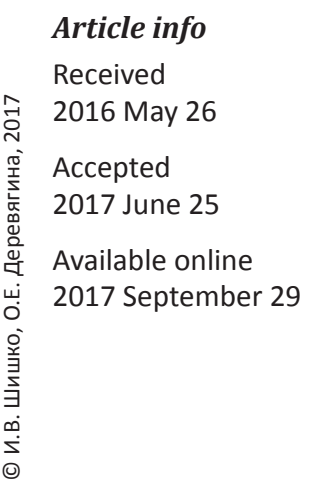

\begin{abstract}
The paper researches all elements of the objective aspect of restricting competition. The interpretation of these elements presents some difficulties caused by the changes in the disposition of Part 1, Art. 178 of the CC of the RF, its blanket character and the complexity of the antimonopoly legislation that was updated by the "fourth anti-monopoly package». The authors research all elements of a cartel agreement - the agreement, its sides and consequences to which it leads or might lead - to distinguish the unlawful restriction of competition from those illegal agreements that do not fall into the category of cartel agreements or from the coordinated activities of businesses that superficially resemble a cartel. These consequences (the authors call them consequences - elements of the cartel itself to differentiate them from the consequences of crime described in part 1 Art. 178 of the $\mathrm{CC}$ ) and the description of the parties in a cartel make it possible to recognize it among other unlawful agreements. The authors conclude that amendments to part 1, Art. 178 of the $\mathrm{CC}$ and notes to this Article resulted in a considerable de-criminalization of restricting
\end{abstract}




\section{Keywords}

Restricting competition; making an agreement that restricts competition; elements of a cartel; competing business; prohibition of an agreement by the antimonopoly legislation of the Russian Federation competition, while antimonopoly legislation novels lead to its partial criminalization. Taking into consideration the legislative recognition of cartels as agreements that unavoidably lead to restricting competition and are, thus, definitely prohibited (per se), the authors analyze the reasons why the objective aspects of crime include such elements as the prohibition of agreement in the antimonopoly legislation of the RF and the restriction of competition. In the end, the authors recognize that these elements are necessary as they minimize the risk of recognizing other unlawful agreements as cartels or criminalizing a cartel that is permissible as an exception.

\section{Acknowledgements}

State Task for Research № 2014/52 within the basic part of the Project № 2706 «Criminal Law and Criminological Aspects of Crime Counteraction»

Одним из ключевых источников экономического развития и, соответственно, экономического роста специалисты называют конкуренцию [1, c. 6]. Между тем по уровню развития конкуренции на рынках товаров и услуг в 2013 г. Россия находилась на 135-м месте [2, с. 72]. «Полученные консервативные количественные оценки последствий недостаточного развития конкуренции... отмечают в литературе, - позволили сделать вывод о том, что ежегодно российский ВВП недопроизводится как минимум на несколько процентных пунктов, что в абсолютном выражении измеряется триллионами рублей (денежный эквивалент недополученного выигрыша потребителей может быть значительно больше)» [1, с. 6]. Вот почему в период экономических затруднений роль конкуренции повышается [3, с. 31], а следовательно, повышается значение охраны конкуренции, в том числе уголовно-правовой.

Несмотря на то что самое распространенное нарушение антимонопольного законодательства - злоупотребление доминирующим положением, т.е. использование хозяйствующим субъектом, занимающим значительную долю на рынке, своей «рыночной силы» в ущерб интересам экономики и потребителей, ст. 178 УК РФ устанавливает уголовную ответственность единственно за картельные соглашения, характеризующиеся определенными признаками. Это обусловлено тем, что картели - самая опасная форма монополистической деятельности. Поведение хозяйствующих субъектов, вступивших в антиконкурентные соглашения (сговор), по результатам тождественно поведению хозяйствующих субъектов, занимающих на рынке доминирующее положение, но его сложно обнаружить: каждый участник соглашения имеет «обычные» экономические характеристики. Вот почему выявление и уничтожение картелей является важной частью политики в области конкуренции в большинстве стран ${ }^{1}$.

Единичность случаев возбуждения уголовных дел о картелях ${ }^{2}$ не отражает их реальное распространение. «Картельные сговоры - это главная болезнь российской экономики... За «дикие» 90-е и 2000-е из-за того, что этой проблемой мало занимались, - отмечает руководитель ФАС России, - картельные сговоры распространились повсеместно» ${ }^{3}$.

Исследование объективных признаков преступного ограничения конкуренции актуализирует также последнее изменение редакции ст. 178 УК $^{4}$ и новеллы в Федеральном законе «О защите конкуренции» ${ }^{5}$ (далее - Закон).

Корректировка указанной нормы УК повлекла существенную декриминализацию ограничения конкуренции: из ч. 1 ст. 178 исключено альтернативное деяние - неоднократное злоупотребление доминирующим положением, а

${ }^{1}$ Economics A-Z [Electronic resource]. URL: http:// www.economist.com/research/Economics/alphabetic. cfm?LETTER=C\#cartel.

2 Цифры и факты // Конкуренция и право. 2015. № 6. С. 36 .

${ }^{3}$ Прямая речь. Выступление главы Федеральной антимонопольной службы Игоря Артемьева на расширенном заседании коллегии ФАС [Электронный ресурс] // Комсомольская правда. 2011. 2 марта. URL: http://www.krsk.kp.ru/ daily/25646/809719.

${ }^{4}$ О внесении изменений в статью 178 Уголовного кодекса Российской Федерации : федер. закон от 8 марта 2015 г. № 45-Ф3 // Собрание законодательства РФ. 2015. № 10. Ст. 1415.

5 О внесении изменений в Федеральный закон «О защите конкуренции» и отдельныезаконодательные акты Российской Федерации : федер. закон от 5 окт. 2015 г. № 275-Ф3 // Там же. № 41 (ч. 1). Ст. 5629. 
понятие крупных (особо крупных) ущерба и дохода в примечаниях к названной статье увеличено в десять раз.

В настоящее время объективная сторона этого преступления включает: заключение между хозяйствующими субъектами - конкурентами ограничивающего конкуренцию соглашения (картеля), запрещенного в соответствии с антимонопольным законодательством Российской Федерации (деяние), ограничение конкуренции (обязательное последствие) и, кроме того, такие альтернативные признаки, как причинение крупного ущерба гражданам, организациям или государству (второе последствие) либо извлечение дохода в крупном размере (доход характеризует масштаб деяния). Разумеется, между деянием и последствиями должна быть установлена причинная связь (равно как и связь между деянием и доходом).

Итак, деяние состоит в заключении между хозяйствующими субъектами - конкурентами ограничивающего конкуренцию соглашения (картеля).

Понятие картеля раскрыто в ч. 1 ст. 11 Закона и образовано тремя признаками: соглашение, его сто́роны, а также последствия, к которым соглашение приводит или может привести.

Соглашение в Законе (п. 18 ст. 4) определено как договоренность в письменной форме ${ }^{6}$, содержащаяся в документе или нескольких документах, а также как договоренность в устной форме. На квалификацию соглашения по ст. 178 УК его форма (письменная или устная) не влияет. На практике случаи заключения документальных картельных соглашений чрезвычайно редки [5, с. 23]. Вместе с тем письменная форма соглашений встречается, и одна из ее разновидностей - договоры.

Ранее для установления письменной формы соглашения арбитражные суды проверяли, соответствует ли оно положениям ГК РФ о сделках и договорах (например, ч. 1 ст. 432, ч. 2 и 3 ст. 434), и в случае несоответствия письменного соглашения требованиям ГК делали вывод об отсутствии антиконкурентных соглашений [6, с. 15]. Однако ограничивающие конкуренцию соглашения - это правонарушения, и соблюдение либо

6 Соглашением в письменной форме может признаваться внутренняя переписка хозяйствующих субъектов, факсовое сообщение, сообщение по электронной почте, СМС-сообщение [4]. игнорирование норм ГК РФ на факт наличия анктиконкурентного соглашения не влияет ${ }^{7}$.

С другой стороны, соответствие договора требованиям ГК вовсе не исключает, что такой договор содержит признаки картельного соглашения. В литературе отмечают: «Подавляющее большинство предприятий даже не подозревают, что многие договоры, которые рассматриваются ими как обычная деловая практика, являются антиконкурентными соглашениями...» $[7$, с. 51].

Сторонами картеля могут быть только хозяйствующие субъекты - конкуренты, т.е. хозяйствующие субъекты, осуществляющие продажу товаров на одном товарном рынке или приобретение товаров на одном товарном рынке (иначе говоря, представители только одной стороны рынка). Хозяйствующие субъекты приобретатели включены в понятие картеля Федеральным законом «О внесении изменений в Федеральный закон «О защите конкуренции» и отдельные законодательные акты Российской Федерации» от 5 октября 2015 г. № 275-ФЗ. Таким образом, с момента вступления названного федерального закона в силу понятие картеля расширено, следовательно, «расширен» круг деяний, подпадающих под ст. 178 УК $^{8}$.

Ограничивающие конкуренцию соглашения между другими хозяйствующими субъектами (продавцом и покупателем либо субъектами, не конкурирующими на одном товарном рынке или рынке взаимозаменяемых товаров), т.е. между субъектами, не являющимися конкурентами, картелем не признаются и, следовательно, объективную сторону данного преступления не образуют.

${ }^{7}$ Постановление Президиума ВАС РФ от 21 декабря 2010 г. № 9966/10 по делу № А27-12323/2009 // Вестник Высшего арбитражного суда РФ. 2011. 4 апр.

${ }^{8}$ Ранее изменения в не уголовном законодательстве также привели к частичной криминализации ограничения конкуренции. В частности, Федеральный закон «О внесении изменений в Федеральный закон «О защите конкуренции» и отдельные законодательные акты Российской Федерации» от 6 декабря 2011 г. № 401-Ф3 уточнил дефиницию хозяйствующего субъекта (п. 5 ст. 4): круг хозяйствующих субъектов был дополнен лицами, не зарегистрированными в качестве индивидуальных предпринимателей, но осуществляющими профессиональную деятельность, приносящую им доход, в соответствии с федеральными законами на основании государственной регистрации и (или) лицензии, а также в силу членства в саморегулируемой организации (например, патентный поверенный, арбитражный управляющий, оценщик, занимающийся частной практикой [8, с. 176]. 
Для решения вопроса, являются ли конкретные хозяйствующие субъекты конкурентами, необходимо установить осуществление ими деятельности на одном товарном рынке. Согласно Порядку проведения анализа состояния конкуренции на товарном рынке (п. 10.3) ${ }^{9}$, установление этого обстоятельства осуществляется антимонопольным органом в четыре этапа: определяется временной интервал исследования товарного рынка, продуктовые и географические границы товарного рынка, а затем - наличие между субъектами конкурентных отношений.

Вид рынка (авиаперевозок, производства молочной продукции, страхования и др.) на квалификацию соглашения не влияет.

С учетом того что сторонами картельного соглашения являются конкуренты-продавцы либо конкуренты-покупатели, необходимо уточнить, что оно может содержаться только в договорах с общей целевой направленностью. Типичный вид таких договоров - договор о совместной деятельности. На практике картелесодержащие договоры могут иметь иное наименование (например, о сотрудничестве $)^{10}$ либо не именоваться вообще, что не запрещено ГК РФ.

Договоры со встречной целевой направленностью (купли-продажи, аренды и др.) картельных соглашений содержать не могут (но могут содержать условия, свидетельствующие об участии одной стороны договора в картельном соглашении).

Третий обязательный признак картеля одно из его пяти альтернативных последствий, указанных в ч. 1 ст. 11 Закона. Перечень последствий картеля, в отличие от последствий иных антиконкурентных соглашений, исчерпывающий. При этом картелем признается соглашение, которое не только приводит, но и может привести к одному из пяти последствий.

Первое последствие - установление или поддержание цен (тарифов), скидок, надбавок (доплат) и (или) наценок. Оно может проявляться в сходной динамике цен (тарифов) на товар в течение определенного периода, в еди-

${ }^{9}$ Об утверждении Порядка проведения анализа состояния конкуренции на товарном рынке [Электронный ресурс] : приказ ФАС России от 28 апр. 2010 г. № 220 (зарегистрировано в Минюсте России 2 авг. 2010 г. № 18026) // СПС «КонсультантПлюс».

${ }_{10}$ Решение Московского областного УФАС России от 14 декабря 2012 г. по делу № 09-22/2-12 [Электронный pecypc]. URL: http://mo.fas.gov.ru/sites/mo.f.isfb.ru/files/ solution/2013/01/10/novoe_reshenie.pdf. ных ценах и тарифах, наценках и надбавках и др. $[9$, c. 55]

Второе последствие - повышение, снижение или поддержание цен на торгах ${ }^{11}$. О картельном сговоре на торгах могут свидетельствовать: одновременный отзыв своих заявок участниками торгов после окончания приема заявок (остается только один участник); предоставление участниками торгов идентичных заявок; соглашение о заблаговременном определении победителей торгов на основе ротации, географического распределения или на основе распределения покупателей; победа в большинстве торгов одного хозяйствующего субъекта [10-12] и др.

На практике встречаются случаи слаженного взаимодействия нескольких юридических лиц, фактически управляемых одним лицом. Например, лицо создает несколько юридических лиц через подставных лиц и «дирижирует» их действиями на торгах. Поскольку созданные таким образом юридические лица - не конкуренты, то их слаженное взаимодействие картелем признаваться не может.

Следующее последствие картеля - раздел товарного рынка по территориальному принципу, объему продажи или покупки товаров, ассортименту реализуемых товаров либо составу продавцов или покупателей (заказчиков). Подобные соглашения на практике встречаются часто и более устойчивы, чем ценовые картели (т.е. картели, приводящие или могущие привести к двум первым последствиям картеля). Обычно крупные компании-поставщики устно договариваются о “своих» территориях поставок продукции, покупателях или продавцах, либо так же устно согласовывают объемы и ассортимент поставляемой или приобретаемой продукции. «Симптомами» раздела рынка называют: разделение клиентов на "своих» и "чужих»; осуществление хозяйственной деятельности в определенных географических районах; отсутствие интереса к определенным контрагентам, территориям, подрядам; искусственное сдерживание предложения товаров, несмотря на наличие спроса [13]. Соглашением может предусматриваться раздел товарного рынка од-

11 Дела о сговорах на торгах (big rigging) в России получили большое распространение. Как отметил начальник Управления по борьбе с картелями А.П. Тенишев, из 409 дел, возбужденных в 2015 г. территориальными органами ФАС России, две трети составляли картели на торгах (URL: http://fas.gov.ru/press-center/ news/detail.html?id=44886). 
новременно по нескольким критериям (например, по территориальному принципу и составу клиентов) [14, р. 42].

Примером раздела рынка по объему продаж является временное придерживание медицинских товаров аптеками (разумеется, по соглашению) в начале эпидемий гриппа для создания искусственного дефицита этих товаров и последующего повышения цен на них.

Четвертое последствие картеля - сокращение или прекращение производства товаров. Сокращение производства - это снижение объема выпуска товаров, прекращение производства отказ от дальнейшего производства. При этом под товаром следует понимать не всю производимую продукцию, а только ту, о сокращении (прекращении) выпуска которой заключено соглашение.

Пятое последствие картеля - отказ от заключения договоров с определенными продавцами или покупателями (заказчиками). Заключение хозяйствующими субъектами различных договоров нацелено на организацию экономической деятельности, поэтому отказ от заключения договоров с какими-либо хозяйствующими субъектами может повлечь нерентабельность их экономической деятельности или невозможность ее осуществления. При установлении этого последствия важно не определить вид договора, в заключении которого отказано (обязательный он для заключения или нет), а выявить наличие соглашения, из-за которого с конкретным контрагентом не заключается договор.

Одно соглашение может содержать и несколько последствий картеля ${ }^{12}$.

Пять перечисленных последствий являются обязательными альтернативными признаками картельного соглашения (назовем их последствиями - признаками самого картеля, чтобы не путать с последствиями преступления, описанными в ч. 1 ст. 178 УК). Если хотя бы одного из этих последствий-признаков нет, нет и картеля.

Установление факта заключения соглашения, которое приводит или может привести к любому из пяти последствий - признаков картеля, означает установление нарушения антимоно-

12 Решение по делу № 05-02/2007-69 от 7 ноября 2007 г. [Электронный ресурс] // ФАСРоссии. Борьбаскартелями. Практика 2008 года (краткие описания дел). URL: https://docviewer.yandex.ru/?url=http\%3A\%2F\%2Fwww. concurencia-ru.ru\%2Ffails\%2Fanalitika\%2Fborba-skartelyami-praktika-2008.doc\&name=borba-s-kartelyamipraktika-2008.doc\&lang=ru\&c=57433d7f60a8 ; Решение по делу № 111/2-11 от 12 апреля 2011 г. См.: [15]. польного законодательства, а именно ч. 1 ст. 11 Закона, за которое, как и за другие соглашения, ограничивающие конкуренцию и недопустимые в соответствии с антимонопольным законодательством РФ, установлена административная ответственность (ч. 1 ст. 14.32 КоАП РФ).

Для признания заключения картельного соглашения преступлением необходимо не только установить ограничивающий конкуренцию характер соглашения и запрещенность этого соглашения в соответствии с антимонопольным законодательством РФ (эти два признака присущи и административно наказуемому заключению противоправного соглашения), но и дополнительно установить признак «ограничение конкуренции», а также один из двух типичных криминообразующих признаков - причинение крупного ущерба гражданам, организациям или государству либо извлечение дохода в крупном размере.

Рассмотрим все перечисленные признаки.

Картель, как и другие соглашения, названные в ст. 11 Закона, относится к ограничивающим конкуренцию: указанная статья так и озаглавлена - «Запрет на ограничивающие конкуренцию соглашения хозяйствующих субъектов». Однако сравнение ч. 1 (определяет понятие картеля) и ч. 4 (устанавливает запрет иных соглашений) этой статьи позволяет установить, что иные соглашения между хозяйствующими субъектами запрещены только при условии, что приводят или могут привести к ограничению конкуренции. В ч. 1 ст. 11 Закона такого условия запрета картеля, как ограничение им конкуренции (способность ее ограничения), нет, и, следовательно, картель всегда признается соглашением, ограничивающим конкуренцию.

К выводу о том, что картели неизбежно влекут ограничение конкуренции, подводит и сравнение ч. 1 ст. 11 и ч. 1 ст. 13 Закона.

На то, что доказывать ограничение картельными соглашениями конкуренции не требуется, указывают многие авторы [16, с. 132; 17]. Картели, отмечают в конкурентно-правовой литературе, неминуемо влекут ограничение конкуренции путем осуществления указанных в ч. 1 ст. 11 Закона действий (ряд авторов именуют последствия - признаки картеля действиями). В этом состоит их отличие от иных антиконкурентных соглашений, которые в зависимости от обстоятельств могут (или не могут) привести к негативным последствиям [18; 19].

Таким образом, признак «ограничивающий конкуренцию» присущ любому картельному со- 
глашению и претендует на признание лишним в диспозиции ч. 1 ст. 178 УК.

Таким же ненужным можно было бы считать и признак «запрещенный в соответствии с антимонопольным законодательством»: в силу того что картельные соглашения неизбежно ограничивают конкуренцию, их запрет является безусловным. «...Запрет на картели являлся и является безусловным, или, как такой запрет называют в мировой юридической науке, запретом per se» [16, с. 132]. О разграничении запрещенных соглашений на соглашения, запрещенные безусловно (per se), и соглашения, запрещаемые при условии ограничения конкуренции, указано и в письме ФАС России «О применении «третьего антимонопольного пакета» от 27 декабря 2011 г. № ИА/48801. В соответствии с п. 7 этого письма картель относится к безусловным запретам.

Вместе с тем включение обоих признаков в ч. 1 ст. 178 УК не лишено смысла: они ориентируют правоприменителя на то, что их наличие нужно перепроверить. Дело в том, что в Законе предусмотрены случаи, когда соглашения не могут быть признаны картелем (ч. 7, 8 и 10 ст. 11) либо в порядке исключения допускаются (ч. 1 ст. 13).

Так, антимонопольное законодательство не запрещает соглашения между хозяйствующими субъектами, входящими в одну группу лиц, если один из таких хозяйствующих субъектов в отношении другого хозяйствующего субъекта установил контроль либо такие хозяйствующие субъекты находятся под контролем одного лица (п. 7 ст. 11 Закона ${ }^{13}$ ). Под контролем понимается возможность физического или юридического лица прямо или косвенно (через юридическое лицо или несколько юридических лиц) определять решения, принимаемые другим юридическим лицом, посредством одного или нескольких действий, указанных в п. 8 ст. 11 Закона. Суть этого положения в том, «чтобы исключить применение запретов ст. 11 Закона о защите конкуренции к соглашениям, которые заключаются внутри одного бизнес-организма, имеющего единую цель на рынке» [17]. В этом случае отсутствует такой обязательный признак

${ }^{13}$ В этом пункте установлено и условие, при наличии которого соглашения указанных выше лиц картелем признаются. Таким условием названо соглашение между субъектами, осуществляющими виды деятельности, одновременное выполнение которых одним субъектом не допускается в соответствии с законодательством РФ. картельного соглашения, как его стороны (нет конкурентов).

Отметим, что остальные признаки, соответствие которым позволяет признать совокупность физических и (или) юридических лиц группой лиц (ст. 9 Закона), дают возможность считать субъектов, входящих в такую группу, субъектами картельного соглашения.

Не признаются картелем и соглашения о совместной деятельности, заключенные с предварительного согласия антимонопольного органа, полученного в установленном порядке (ч. 10 ст. 11 Закона): такое согласие может быть получено исключительно при установлении отсутствия угрозы конкуренции.

Кроме того, признак «запрещенный в соответствии с антимонопольным законодательством» отсутствует, если соглашение, включая картельное, допускается. В частности, согласно ч. 1 ст. 13 Закона, могут быть признаны допустимыми соглашения хозяйствующих субъектов - конкурентов о совместной деятельности, если такими соглашениями не создается возможность для отдельных лиц устранить конкуренцию на соответствующем товарном рынке, на их участников или третьих лиц не налагаются ограничения, не соответствующие достижению целей таких соглашений, а также если их результатом является или может являться:

- совершенствование производства, реализации товаров или стимулирование технического, экономического прогресса либо повышение конкурентоспособности товаров российского производства на мировом товарном рынке;

- получение покупателями преимуществ (выгод), соразмерных преимуществам (выгодам), полученным хозяйствующими субъектами в результате соглашений.

Подчеркнем, допустимыми могут признаваться не любые соглашения, которые могут привести к последствиям - признакам картеля, а единственно соглашения о совместной деятельности.

Вызывает сомнение обоснованность сохранения в ч. 1 ст. 178 УК признака «ограничение конкуренции» (в предыдущей редакции этой нормы наряду с ним упоминались недопущение и устранение конкуренции).

Понятие ограничения конкуренции Закон не раскрывает, но перечисляет признаки ограничения конкуренции (п. 17 ст. 4): сокращение числа хозяйствующих субъектов, не входящих в одну группу лиц, на товарном рынке; рост или 
снижение цены товара, не связанные с соответствующими изменениями иных общих условий обращения товара на товарном рынке; отказ хозяйствующих субъектов, не входящих в одну группу лиц, от самостоятельных действий на товарном рынке; определение общих условий обращения товара на товарном рынке соглашением между хозяйствующими субъектами или в соответствии с обязательными для исполнения ими указаниями иного лица либо в результате согласования хозяйствующими субъектами, не входящими в одну группу лиц, своих действий на товарном рынке; иные обстоятельства, создающие возможность для хозяйствующего субъекта или нескольких хозяйствующих субъектов в одностороннем порядке воздействовать на общие условия обращения товара на товарном рынке. Как видно, ограничение конкуренции проявляется в объективных изменениях на рынке, и установить признак «ограничение конкуренции» - значит установить, что указанные объективные изменения на рынке произошли. Эти изменения - обязательное последствие преступления, без установления которого преступление не может быть признано оконченным (разумеется, наряду с этим последствием должен быть установлен крупный ущерб либо крупный доход).

Вместе с тем отнесение картелей к запрещенным безусловно (per se) означает, что «антимонопольный орган, расследуя дело о нарушении антимонопольного законодательства по части 1 статьи 11 Закона, не устанавливает вредоносное воздействие картеля на конкуренцию (курсив наш. - И. Ш., О. Д.), а лишь квалифицирует такое соглашение как незаконное по формальным основаниям - по цели соглашения и природе отношений, в которых состоят стороны соглашения - конкуренты» [16, с. 132]. Именно в связи с этим по делам о картелях анализ состояния конкуренции на товарном рынке включает всего четыре этапа ${ }^{14}$, направленных на установление деятельности сторон на одном товарном рынке, без оценки состояния конкуренции на товарном рынке ${ }^{15}$.

14 Пункт 10.3 Порядка проведения анализа состояния конкуренции на товарном рынке.

${ }^{15}$ По делам об иных соглашениях анализ состояния конкуренции включает все десять этапов (с оценкой состояния конкуренции на товарном рынке) (п. 1.3 Порядка проведения анализа состояния конкуренции на товарном рынке).
Показательно, что еще в период действия ст. 178 УК в редакции федерального закона от 6 декабря 2011 г. № 401-Ф3 Правительство вносило в Государственную Думу проект федерального закона «О внесении изменений в статью 178 Уголовного кодекса Российской Федерации и в отдельные законодательные акты Российской Федерации» ${ }^{16}$, направленный на исключение признака «недопущение, ограничение или устранение конкуренции» из ч. 1 ст. 178 УК. В пояснительной записке к законопроекту отмечалось, что действующая редакция позволяет правоприменителю исходить из того, что уголовному преследованию подлежит не сам по себе картельный сговор, повлекший причинение ущерба или извлечение дохода в соответствующем размере, а лишь такой сговор, который привел к недопущению, устранению или ограничению конкуренции. Подобное толкование и основанное на нем применение ч. 1 ст. 178 УК, отмечалось в пояснительной записке, противоречит смыслу понятия картельного соглашения как одного из наиболее опасных посягательств на основы экономики, а также цели предупреждения таких соглашений на ранней стадии их реализации ${ }^{17}$.

Как видим, признак «ограничение конкуренции» по-прежнему противоречит смыслу понятия картеля, усложняет применение ст. 178 УК ввиду «трудоемкости его установления» [20, с. 55], но, будучи сохраненным в ч. 1 ст. 178 УК, требует доказывания.

Вместе с тем нельзя не отметить существование аргументов и в пользу сохранения этого признака: сложность идентификации соглашений как картельных; благоприятные условия для возбуждения дела, а также формального анализа обстоятельств дела в условиях ограниченных возможностей фильтрации жалоб юридических или физических лиц [21, с. 46]; появившиеся сомнения в запрете картелей согласно букве закона [там же, с. 34-35]; и, кроме того, способность ряда действий участников рынка одновременно

${ }^{16}$ О проекте Федерального закона «О внесении изменений в статью 178 Уголовного кодекса Российской Федерации и отдельные законодательные акты Российской Федерации» : распоряжение Правительства РФ от 12 апр. 2013 г. № 586-р // Собрание законодательства РФ. 2013. № 16. Ст. 1997.

17 Пояснительная записка к проекту Федерального закона «О внесении изменений в статью 178 Уголовного кодекса Российской Федерации и отдельные законодательные акты Российской Федерации» [Электронный pecypc]. URL: http://asozd2.duma.gov.ru/main.nsf/\%28Sp ravkaNew\%29?OpenAgent\&RN=260190-6\&02. 
ограничивать конкуренцию и повышать эффективность и благосостояние [22, с. 9]. Очевидно, по замыслу законодателя, сохранение признака «ограничение конкуренции» должно исключить признание картелем соглашений, не являющихся таковыми.

«Обременение» названным признаком объективной стороны ограничения конкуренции российским законодателем созвучно установлению жестких требований к доказательствам наличия картеля американскими и европейскими судами [23, р. 524].

Несмотря на законодательное толкование признака «крупный» в примечаниях (пп. 1 и 2) к ст. 178 УК и отражение характера ущерба (реального ущерба и упущенной выгоды) в ведомственных актах ФАС России, проблема установления крупных ущерба или дохода не устранена: единой доктринальной либо нормативно закрепленной методики определения ущерба либо дохода от картельных соглашений не существует.

В литературе для определения ущерба предлагают использовать методы: сравнения цен во время периода картеля с ценами сопоставимого рынка, не характеризующегося деятельностью картеля, или для того же самого рынка, но в течение конкурентоспособного периода [24, р. 222]; построения некоторой регрессионной модели, описывающей ценообразование; сравнения фактической цены картеля с гипотетической ценой в условиях конкуренции [25, с. 135-137] и др.

Эти методы нашли отражение и в проекте Методических рекомендаций ФАС России по определению размера убытка в результате нарушения антимонопольного законодательства ${ }^{18}$ (далее - Проект). При этом Проект не ограничивает перечень допустимых методов определения убытков и в нем отмечено, что ни один из приведенных методов не имеет заведомо приоритетного статуса.

В условиях многообразия предложенных методов, могущих привести к несовпадающим оценкам размера ущерба, определенным «ориентиром» можно считать высказывание Европейской комиссии о предпочтительном использовании метода эталонных рынков, когда в качестве основы для формирования гипотетической ценовой динамики при отсутствии картеля берется близкорасположенный рынок рассматриваемого товара, находящийся в состоянии

18 URL: http://fas.gov.ru/documents/documentdetails. html?id=14354. конкуренции, или рассматривается рынок товара-аналога [25, с. 137].

Различные предложения высказаны в литературе и о способе определения дохода [26; 27].

Не претендуя на разрешение непростого вопроса о методах определения ущерба (дохода), в данной статье хотим обратить внимание на следующее. Картельное соглашение - это как минимум группа лиц по предварительному сговору. Примером такой группы может быть соглашение на торгах. Однако в экономической литературе картельное соглашение считают, как правило, разновидностью долгосрочных контрактных отношений [21, с. 37]. Как отмечают Margaret C. Levenstein и Valerie Y. Suslow, в то время как продолжительность некоторых картелей была менее года, средняя продолжительность известных в истории картелей значительно более длительна (от пяти до шести лет) [28, р. 512].

Действительно, противоправное взаимодействие участников картеля не исчерпывается заключением соглашения. Ограничение конкуренции, крупные ущерб либо доход из самого факта заключения картельного соглашения не появятся. И если действия виновных были пресечены сразу после заключения соглашения, то привлечение к ответственности за ограничение конкуренции возможно только по ч. 3 ст. 30 и ч. 1 ст. 178 УК, т.е. за покушение (при доказанности желания виновного извлечь доход в крупном размере). Реально последствия причиняет (позволяет извлечь доход) реализация картельного соглашения, не отраженная в описании объективной стороны: установление или поддержание цен, раздел рынка, сокращение или прекращение производства товаров... Эта реализация обеспечивается взаимным контролем участников, применением «санкций» к участникам-оппортунистам, корректировкой соглашений [21, с. 39; 29, с. 128] и т.д. Таким образом, преступное взаимодействие участников картеля, как правило, носит устойчивый характер, следовательно, картель - это, как правило, организованная группа.

Итак, всем участникам картеля (руководителям всех участников картеля - юридических лиц) необходимо вменять всю сумму ущерба (дохода) от картельного соглашения за весь период его существования независимо от размера ущерба (дохода), причиненного (полученного) конкретным хозяйствующим субъектом.

Указанный выше взаимный контроль участников картеля позволяет утверждать, что потерпевшим - лицом, к которому применяются на- 
силие либо угроза его применения (ч. 3 ст. 178 УК), - может быть участник картеля (руководитель участника картеля), нарушивший условия соглашения ${ }^{19}$. Другими способами обеспечить исполнение противоправного соглашения трудно.

Учитывая возможность квалификации заключения соглашения как покушения на преступление, предусмотренное ст. 178 УК, уголовноправовое значение приобретает вопрос о том, входят ли в понятие заключения картельного соглашения действия по организации (достижению) заключения соглашения (например, назначение конкурентам встречи с обозначением

${ }^{19}$ Насилие (угрозы его применения) может применяться и к конкурентам, не являющимся участниками картеля, экономические интересы которых нарушаются действиями картеля. вопроса для обсуждения, направление хозяйствующим субъектам - конкурентам проекта соглашения и т.д.). С нашей точки зрения, действия по достижению соглашения еще не образуют заключения соглашения. В соответствии с ч. 1 ст. 11 Закона признаются картелем и запрещаются соглашения между хозяйствующими субъектами конкурентами, если такие соглашения приводят или могут привести к указанным в этой норме последствиям. Очевидно, что действия «по достижению» к указанным последствиям привести не могут: договоренность еще не достигнута.

Названные организационные действия могут квалифицироваться как приготовление к ограничению конкуренции, предусмотренному ч. 2 или 3 ст. 178 УК (т.е. к ограничению конкуренции, относящемуся к тяжким преступлениям).

\section{СПИСОК ИСПОЛЬЗОВАННОЙ ЛИТЕРАТУРЫ}

1. Последствия слабой конкуренции: количественные оценки и выводы для политики (экспертно-аналитический доклад) / А. Шаститко, С. Голованова, П. Крючкова, А. Курдин, В. Новиков, М. Овчинников, Н. Павлова // Экономическая политика. - 2012. - № 6. - С. 5-53.

2. Мальцева О.В. Анализ проблем и оценка уровня развития конкуренции в России / О.В. Мальцева // Journal of economic regulation. - 2014. - Т . 5, № 1. - С. 69-76.

3. Юсупова Г.Ф. Проблемы противодействия ограничивающим конкуренцию соглашениям в российской антимонопольной политике / Г.Ф. Юсупова // Современная конкуренция - 2009. - № 2. - С. 31-42.

4. Борзило Е.Ю. Антимонопольные риски предпринимательской деятельности. Научно-практическое руководство / Е.Ю. Борзило. - М. : Статут, 2014. - 335 с.

5. Тенишев А. Дела о картелях: итоги-2014 / А. Тенишев // Конкуренция и право. - 2014. - № 6. - С. 22-23.

6. Соколовская Е. Проблемы квалификации антиконкурентных соглашений / Е. Соколовская // Конкуренция и право. - 2011. - № 3. - С. 15-18.

7. Шоломова Е.В. Антиконкурентное соглашение: как распознать / Е.В. Шоломова // Промышленность: бухгалтерский учет и налогообложение. - 2012. - № 3. - С. 51-69.

8. Шишко И.В. Субъект ограничивающего конкуренцию соглашения (картеля) / И.В. Шишко, О.Е. Деревягина // Вестник Омского университета. Сер. «Право». - 2014. - № 1 (38). - С. 173-180.

9. Князева И.В. Антимонопольная политика в России : учеб. пособие / И.В. Князева. - 5-е изд., перераб. - М. : Омега-Л, 2011. - 380 с.

10. Хабаров С.А. Сговор как форма координации на торгах / С.А. Хабаров // Юрист. - 2014. - № 15. - С. 33-37. C. $35-40$.

11. Карлин Ф. Картельный сговор при проведении тендера / Ф. Карлин // Корпоративный юрист. $-2007 .-$ № 5. -

12. Кинев А.Ю. Картели и другие антиконкурентные соглашения: право и практика / А.Ю. Кинев. - М. : Инфотропик, 2011. -368 c.

13. Кинев А.Ю. Картели и другие антиконкурентные соглашения [Электронный ресурс] / А.Ю. Кинев // СПС КонсультантПлюс. - Режим доступа: http://base.consultant.ru/cons/cgi/online.cgi?req=home.

14. Bhattacharjea A. Multi-market collusion with territorial allocation / A. Bhattacharjea, U. Sinha // International Journal of Industrial Organization. - 2015. - Vol. 41. - P. 42-50. - DOI: 10.1016/j.ijindorg.2015.05.003.

15. Артемьев И.Ю. От «спичек» до «соли». Борьба с картелями. Лучшие практики 2008-2013 / И.Ю. Артемьев, А.Ю. Цариковский, А.Ю. Кинев. - М., 2013. - 542 с.

16. Картели. Система доказывания и судебная практика / А.Ю. Кинев, Н.Н. Егорычев, П.В. Самолысов, А.П. Тенишев // Закон. - 2013. - № 4. - С. 131-138.

17. Дианов В. Комментарий к «третьему антимонопольному пакету» : учеб. пособие / В. Дианов, А. Егорушкин, Е. Хохлов. - М. : Статут, 2012. - 256 с.

18. Комментарий к Федеральному закону “О защите конкуренции» (постатейный) / под ред. В.Ф. Попондопуло, Д.А. Петрова. - М. : Инфра-М, 2013. - 542 с.

19. Комментарий к Федеральному закону от 26 июля 2006 г. № 135-Ф3 «О защите конкуренции» (постатейный) [Электронный ресурс] / отв. ред. И.Ю. Артемьев // СПС КонсультантПлюс. - Режим доступа: http://base.consultant.ru/cons/cgi/ online.cgi?req=home.

20. Андреященко Е. К вопросу о методологии анализа картельных соглашений / Е. Андреященко, А. Заздравных // Вопросы экономики. - 2014. - № 9. - С. 53-64. 
21. Шаститко А.Е. Картель: организация, стимулы, политика противодействия / А.Е. Шаститко // Российский журнал менеджмента. - 2013. - Т. 11, № 4. - С. 31-56.

22. Авдашева С.Б. Конкурентная политика: состав, структура, система / С.Б. Авдашева, А Е. Шаститко // Вопросы теории конкуренции. - 2010. - № 1 (19). - С. 5-20.

23. Hüschelrath K. How Are Cartels Detected? The Increasing Use of Proactive Methods to Establish Antitrast Infringements / K. Hüschelrath // Journal of European Competition Law and Practical. - 2010. - Vol. 1, № 6. - P. 522-528.

24. Boshoff W.H. Illegal cartel overcharges in markets with a legal cartel history: bitumen prices in South Africa / W.H. Boshoff // South African Journal of Economics. - 2015. - Vol. 83, iss. 2. - P. 220-239.

25. Алешин Д.А. Экономический анализ в практике зарубежного антимонопольного регулирования / Д.А. Алешин, И.В. Князева, А.Г. Сушкевич. - Новосибирск : Изд-во НГТУ, 2016. - 246 с.

26. Солодилова Э.Д. Извлечение дохода в крупном размере как признак преступного картеля / Э.Д. Солодилова // Уголовное право. - 2011. - № 6. - С. 49-52.

27. Деревягина О.Е. Крупный ущерб как криминообразующий признак недопущения, ограничения или устранения конкуренции / О.Е. Деревягина // Российский следователь. - 2008. - № 16. - С. 23-27.

28. Kallioinen M. Cartel success and institutions. The Finnish Cotton Cartel, 1903-1939 / M. Kallioinen // Business History. 2015. - Vol. 57 (4). - P. 512-527.

29. Гришина А.С. Факторы, определяющие цены картеля / А.С. Гришина // Вестник науки и образования. - 2015. № 4 (6). - C. 128-130.

\section{REFERENCES}

1. Shastitko A., Golovanova S., Kryuchkova P., Kurdin A., Novikov V., Ovchinnikov M., Pavlova N. Consequences of weak competition: quantitative evaluations and political conclusions (expert-analytical report). Ekonomicheskaya politika = Economic Policy, 2012, no. 6, pp. 5-53. (In Russian).

2. Mal'tseva O.V. Problem analysis and the evaluation of competition development in Russia. Journal of Economic Regulation, 2014, no. 5 (1), pp. 69-76. (In Russian).

3. Yusupova G.F. Problems of counteracting agreements that limit competition in Russian antimonopoly policy. Sovremennaya konkurentsiya $=$ Modern Competition, 2009, no. 2, pp. 31-42. (In Russian).

4. Borzilo E.Yu. Antimonopol'nye riski predprinimatel'skoi deyatel'nosti. Nauchno-prakticheskoe rukovodstvo [Antimonopoly Risks of Entrepreneurship. A Scientific Manual]. Moscow, Statut Publ., 2014. 335 p.

5. Tenishev A. Cases of cartels: results of 2014. Konkurentsiya i pravo = Competition and Law, 2014, no. 6, pp. 22-23. (In Russian).

6. Sokolovskaya E. Problems of classifying anti-competition agreements. Konkurentsiya i pravo = Competition and Law, 2011, no. 3, pp. 15-18. (In Russian).

7. Sholomova E.V. Anticompetition agreement: recognizing it. Promyshlennost': bukhgalterskii uchet $i$ nalogooblozhenie = Industry: Accounting and Taxation, 2012, no. 3, pp. 51-69. (In Russian).

8. Shishko I.V., Derevyagina O.E. The subject of an agreement (cartel) that limits competition. Vestnik Omskogo universiteta. Seriya "Pravo» = Bulletin of Omsk University. Series Law: 2014, no. 1 (38), pp. 173-180. (In Russian).

9. Knyazeva I.V. Antimonopol'naya politika v Rossii [Antimonopoly Policy in Russia]. $5^{\text {th }}$ ed. Moscow, Omega-L Publ., 2011.380 p.

10. Khabarov S.A. Collusion as a form of coordination during tenders. Yurist = Lawyer, 2014, no. 15, pp. 33-37. (In Russian).

11. Karlin F. Cartel collusion during tenders. Korporativnyi yurist = Corporate Lawyer, 2007, no. 5, pp. 35-40. (In Russian).

12. Kinev A.Yu. Karteli i drugie antikonkurentnye soglasheniya: pravo i praktika [Cartels and Other Anti-Competition Agreements: Law and Practice]. Moscow, Infotropik Publ., 2011. 368 p.

13. Kinev A.Yu. Karteli i drugie antikonkurentnye soglasheniya: pravo i praktika [Cartels and Other Anti-Competition Agreements: Law and Practice]. Available at: http://base.consultant.ru/cons/cgi/online.cgi?req=home. (In Russian).

14. Bhattacharjea A., Sinha U. Multi-market collusion with territorial allocation. International Journal of Industrial Organization, 2015, vol. 41, pp. 42-50. DOI: 10.1016/j.ijindorg.2015.05.003.

15. Artem'ev I.Yu., Tsarikovski A.Yu., Kinev A.Yu. Ot «spichek» do "soli». Bor'ba s kartelyami. Luchshie praktiki 2008-2013 [From «Matches» to «Salt». Fighting Cartels. Best Practices of 2008-2013]. Moscow, 2013. 542 p.

16. Kinev A.Yu., Egorychev N.N., Samolysov P.V., Tenishev A.P. Cartels. A system of proofing and court practice. Zakon $=$ Law, 2013, no. 4, pp. 131-138. (In Russian).

17. Dianov V., Egorushkin A., Khokhlov E. Kommentarii k "tret'emu antimonopol'nomu paketu» [Comments to the "third anti-monopoly package»]. Moscow, Statut Publ., 2012. 256 p.

18. Popondopulo V.F., Petrov D.A. (eds). Kommentarii k Federal'nomu zakonu "O zashchite konkurentsii» (postateinyi) [Article-by-article Comments to the Federal Law «On Protecting Competition»]. Moscow, Infra-M Publ., 2013. 542 p.

19. Artem'ev I.Yu. (ed.). Kommentarii k Federal'nomu zakonu ot 26 iyulya 2006 g. № 135-FZ "O zashchite konkurencii» (postateinyi) [Comments to the Federal Law of June 26, 2006 № 135-Ф3 «On Protecting Competition» (article-by-article)]. Available at: http://base.consultant.ru/cons/cgi/online.cgi?req=home. (In Russian).

20. Andreyashchenko E., Zazdravnykh A. To the problem of analysis methodology of cartel agreements. Voprosy ekonomiki = Issues of Economy, 2014, no. 9, pp. 53-64. (In Russian).

21. Shastitko A.E. Cartel: organization, stimuli, counteraction policy. Rossiiskii zhurnal menedzhmenta $=$ Russian Journal of Management, 2013, vol. 11, no. 4, pp. 31-56. (In Russian).

22. Avdasheva S.B., Shastitko A.E. Competition policy: composition, structure, system. Voprosy teorii konkurentsii =Issues of the Theory of Competition, 2010, no. 1 (19), pp. 5-20. (In Russian).

23. Hüschelrath K. How Are Cartels Detected? The Increasing Use of Proactive Methods to Establish Antitrast Infringements. Journal of European Competition Law and Practical, 2010, vol. 1, no. 6, pp. 522-528. 
24. Boshoff W.H. Illegal cartel overcharges in markets with a legal cartel history: bitumen prices in South Africa. South African Journal of Economics, 2015, vol. 83, iss. 2, pp. 220-239.

25. Aleshin D.A., Knyazeva I.V., Sushkevich A.G. Ekonomicheskii analiz v praktike zarubezhnogo antimonopol'nogo regulirovaniya [Economic Analysis in the practice of foreign antimonopoly regulation]. Novosibirsk State Technical University Publ., 2016. 246 p.

26. Solodilova E.D. Deriving large income as an element of a criminal cartel. Ugolovnoe pravo = Criminal Law, 2011, no. 6, pp. 49-52. (In Russian).

27. Derevyagina O.E. Major damage as a crime-defining element of preventing, limiting or eliminating competition. Rossiiskii sledovatel' = Russian Investigator, 2008, no. 16, pp. 23-27. (In Russian).

28. Kallioinen M. Cartel success and institutions. The Finnish Cotton Cartel, 1903-1939. Business History, 2015, vol. 57 (4), pp. 512-527.

29. Grishina A.S. Factors defining cartel prices. Vestnik nauki i obrazovaniya = Bulletin of Science and Education, 2015, no. 4 (6), pp. 128-130. (In Russian).

\section{ИНФОРМАЦИЯ ОБ АВТОРАХ}

Шишко Ирина Викторовна - директор Юридического института Сибирского федерального университета, доктор юридических наук, профессор, г. Красноярск, Российская Федерация; e-mail: ir-vic02@yandex.ru.

Деревягина Ольга Евгеньевна - старший преподаватель кафедры коммерческого, предпринимательского и финансового права Юридического института Сибирского федерального университета, г. Красноярск, Российская Федерация; e-mail: d.o.e@mail.ru.

\section{ДЛЯ ЦИТИРОВАНИЯ}

Шишко И.В. Преступное ограничение конкуренции (часть 1 статьи 178 УК РФ): признаки объективной стороны / И.В. Шишко, О.Е. Деревягина // Всероссийский криминологический журнал. - 2017. T. 11, № 3. - C. 551-561. - DOI: 10.17150/25004255.2017.11(3).551-561.

\section{INFORMATION ABOUT THE AUTHORS}

Shishko, Irina V. - Director, Law Institute, Siberian Federal University, Doctor of Law, Professor, Krasnoyarsk, the Russian Federation; e-mail: ir-vic02@yandex.ru.

Derevyagina, Olga E. - Senior Lecturer, Chair of Commercial, Entrepreneurial and Financial Law, Law Institute, Siberian Federal University, Krasnoyarsk, the Russian Federation; e-mail: d.o.e@mail.ru.

\section{FOR CITATION}

Shishko I.V., Derevyagina O.E. Criminal restriction of competition (part 1 of Art. 178 of the Criminal Code of the Russian Federation): objective aspects. Vserossiiskii kriminologicheskii zhurnal = Russian Journal of Criminology, 2017, vol. 11, no. 3, pp. 551-561. DOI: 10.17150/25004255.2017.11(3).551-561. (In Russian). 